\title{
Polyoxometallates as effective photocatalysts in water purification from pesticides*
}

\author{
E. Gkika, ${ }^{1,3}$ P. Kormali, ${ }^{1,2}$ S. Antonaraki, ${ }^{1,2}$ D. Dimoticali, ${ }^{2}$ \\ E. Papaconstantinou, ${ }^{1}$ and A. Hiskia ${ }^{1}$ \\ ${ }^{1}$ Institute of Physical Chemistry, NCSR Demokritos, 153-10, Athens, Greece \\ ${ }^{2}$ Chemical Engineering Department, NTU, 15780 Athens, Greece \\ ${ }^{3}$ Department of Chemistry, National and Capodistrian University of Athens, \\ University Campus, 157-71, Greece
}

\begin{abstract}
Polyoxometallates (POM), i.e., metal oxide clusters of mainly tungsten are effective homogeneous photocatalysts for the mineralization of organic pollutants. POM are, at least, as effective as the well studied $\mathrm{TiO}_{2}$. OH' radicals formed by the reaction of the photo-excited polyoxometallates with $\mathrm{H}_{2} \mathrm{O}$, appear to play a key role in the process. In this study, the photocatalytic activity of POM have been tested on some diversified pesticides of interest such as lindane, bentazone and fenitrothion to determine the feasibility of decontamination of aqueous solutions from these pollutants. The results show that aqueous solutions containing the above pesticides, upon photolysis in the presence of polyoxotungstates undergo effective degradation to $\mathrm{CO}_{2}, \mathrm{H}_{2} \mathrm{O}$ and the corresponding inorganic anions. The intermediates identified give rise to complicated degradation mechanisms prior to mineralization. The characteristic reactions that take place consist of hydroxylation, H-abstraction, dehalogenation, denitration, desulfurization, breaking of the C-C bond etc.
\end{abstract}

\section{INTRODUCTION}

The phocatalytic mineralization of several organic pollutants, i.e., decomposition to $\mathrm{CO}_{2}, \mathrm{H}_{2} \mathrm{O}$ and inorganic ions has been demonstrated using polyoxometallates (POM) [1-3]. These are acid condensation products, mainly of molybdenum and tungsten [4-6], that upon excitation with near visible and UV light become powerful oxidizing reagents capable of destroying a great variety of pollutants in the aquatic environment. $\mathrm{OH}$. radicals generated by reaction of $\mathrm{POM}$ with $\mathrm{H}_{2} \mathrm{O}$ seem to play a key role in the process [7].

POM are at least as effective as the widely published $\mathrm{TiO}_{2}$. Dioxygen is important in that it oxidizes (regenerates) the catalyst and through reductive activation may or may not participate further in the process, depending on the substrate [8].

Lindane is a typical organochlorine insecticide with a remarkable stability in the environment [9]. Although it has been replaced by more polar or photodegradable pesticides, it seems that will be used for many years to come in the developing countries. Bentazone belongs to acidic herbicides that are of great interest within the European Union since they are extensively used in agriculture. Due to their chemical and physical properties they do not attach to soil particles and as a result they leach and may pose problems for resources such as drinking water [10]. Fenitrothion is an insecticide with a typical OP stucture. Like other organophosphorous pesticides fenitrothion is known for its acute toxicity

* Part of this work was presented in the 2nd Mediterranean Meeting on Photochemistry, Sicily Italy, 28th-2nd July 2003.

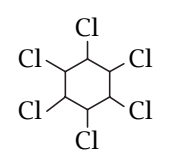

a

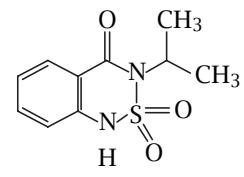

b

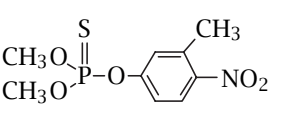

C
Scheme 1. Structures of: $a$, lindane; $b$, bentazone; $c$., fenitrothion.

towards nontarget organisms [11]. The chemical structure of these three pesticides are given in Scheme 1.

The photocatalytic degradation of lindane [12], bendazone [13], and fenitrothion [14] with $\mathrm{TiO}_{2}$ has been investigated in previous studies, whereas limited work has been done with POM concerning lindane $[15,16]$ and fenitrothion [17], respectively.

In this work, we report the complete photocatalytic degradation of the above diversified pesticides, i.e., lindane, bentazone, and fenitrothion, in the presence of $\mathrm{POM}$, by monitoring the final products of the process. We also report on the intermediates involved in the photocatalytic degradation process of fenitrothion, as identified by HPLC-DAD and GC-MS. The three pesticides were chosen as model substrates because they were extensively used in agriculture, belong to the most usual pesticide families and they have very different chemical structures.

\section{EXPERIMENTAL}

2.1. Chemicals and reagents. Lindane (99\%), bentazone (99\%), and fenitrothion (97.5\%) were purchased 
from Dr. Ehrenstorfer. The solvents used (acetonitrile, dichloromethane, ethylacetate) were pesticide residue free grade (Lab scan). Analytical reagent grade perchloric acid $\left(\mathrm{HClO}_{4} 70 \%\right)$ was product of Riedel de Haen. Anhydrous sodium sulphate was purchased from Riedel de Haen. Ultra pure water was obtained by a MilliQ PLUS 185 water system (Millipore). $\mathrm{PW}_{12} \mathrm{O}_{40}{ }^{3-}$ and $\mathrm{SiW}_{12} \mathrm{O}_{40}{ }^{4-}$ was prepared according to methods reported in the literature [18]. Extra pure dioxygen and nitrogen were used for oxygenation and evaporation of solutions.

\subsection{Instrumentation. Photolysis experiments} were performed with a laboratory constructed "illumination box" equipped with four F15W/T8 black light tubes (Sylvania). The maximum emission of these tubes is around $375 \mathrm{~nm}$, emitting $71.7 \mu \mathrm{W} \mathrm{cm}{ }^{-2}$ at a distance of $25 \mathrm{~cm}$.

HPLC analysis was carried out using an HPLC apparatus consisting of a Waters model TM 600 gradient pump, a Waters Model 996 photodiode array detector (DAD) and a Waters 717 Autosampler controlled by the Millenium (Waters) software. The mobile phase composition for the determination of fenitrothion was acetonitrile-water $(50: 50 \mathrm{v} / \mathrm{v})$ and the column used was a Novapak $\mathrm{C}_{18}(4.6 \times 250 \mathrm{~mm}$, i.d. $4 \mu \mathrm{m})$ cartidge column. In the case of bentazone the mobile phase consisted of a gradient eluent $15 \% \mathrm{~A}(\mathrm{ACN} / \mathrm{methanol}=$ $\left.1 / 1+0.001 \% \mathrm{CH}_{3} \mathrm{COOH}\right)-85 \% \mathrm{~B}\left(5 \mathrm{mM} \mathrm{KH} \mathrm{PO}_{4}+\right.$ $0.001 \% \mathrm{CH}_{3} \mathrm{COOH}$ ) at $0 \mathrm{~min}, 50 \% \mathrm{~A}$ at $16 \mathrm{~min}, 55 \% \mathrm{~A}$ at $20 \mathrm{~min}, 15 \%$ A at $21 \mathrm{~min}$, at a flow rate of $0.35 \mathrm{ml} / \mathrm{min}$.

GC analysis was carried out using a Hewlett Packard Model 5890 gas chromatograph equipped with ECD, split-splitless injection port and a DB-l fused silica capillary column by J\&W Scientific Inc. $(30 \mathrm{~m} \times 0.32 \mathrm{~mm}$ l.D., $0.25 \mu \mathrm{m}$ film thickness). The temperature program applied in GC-ECD, for the determination of lindane, was as follows: $80^{\circ} \mathrm{C}$ for $1 \mathrm{~min}, 80^{\circ} \mathrm{C}-218^{\circ} \mathrm{C}$ at $8^{\circ} \mathrm{C} / \mathrm{min}, 218^{\circ} \mathrm{C}$ for $18 \mathrm{~min}, 218^{\circ} \mathrm{C}-250^{\circ} \mathrm{C}$ at $4{ }^{\circ} \mathrm{C} / \mathrm{min}$ and $250^{\circ} \mathrm{C}$ for $10 \mathrm{~min}$. Detector's temperature was held at $300^{\circ} \mathrm{C}$. The injection was carried out splitless at $250^{\circ} \mathrm{C}$ and the injection volume was $1 \mu \mathrm{l}$.

Identification of intermediates were performed using an Agilent 6890 Series gas chromatograph equipped with an HP-5 MS capillary column $(30 \mathrm{~m} \times 0.25 \mathrm{~mm}$ i.d., $0.25 \mathrm{~mm}$ film thickness), interfaced to an Agilent 5973 mass selective detector. Data acquisition, processing and instrument control were performed by the Agilent MSD Chem-Station software. The flow rate was $1.0 \mathrm{ml} / \mathrm{min}$. The temperature programme applied in GC-MS was as follows: $50^{\circ} \mathrm{C}$ for $4 \mathrm{~min}, 5^{\circ} \mathrm{C} / \mathrm{min}$ to $150{ }^{\circ} \mathrm{C}$ for $1 \mathrm{~min}, 5^{\circ} \mathrm{C} / \mathrm{min}$ to $280^{\circ} \mathrm{C}$ for $10 \mathrm{~min}$. Detector's temperature was held at $280^{\circ} \mathrm{C}$. The injection was carried out splitless at $250{ }^{\circ} \mathrm{C}$ and the injection volume was $2.0 \mu \mathrm{l}$.

The $\mathrm{CO}_{2}$ formation was followed by head space gas chromatographic analysis of the gas phase of pyrex cells by GC/MS. The temperature programme was: $40^{\circ} \mathrm{C}$ for $1 \mathrm{~min}, 4.2^{\circ} \mathrm{C} / \mathrm{min}$ to $50^{\circ} \mathrm{C}, 16.7{ }^{\circ} \mathrm{C} / \mathrm{min}$ to $80^{\circ} \mathrm{C}$ for $1.2 \mathrm{~min}$. The injector temperature was $210^{\circ} \mathrm{C}$. The injection was carried out splitless in full scan mode. $100 \mu \mathrm{l}$ were sampled from the headspace and injected for analysis. Extracted chromatograms on ion 44 were used for the detection and quantitation of the $\mathrm{CO}_{2}$ peak.

For the monitoring of inorganic ions an Ionic Chromatograph of Dionex DX-300 which consists of a pulsed electrochemical detector PED-2 dionex and an IonPack AG $14(4 \times 250 \mathrm{~mm})$ analytical column was used. The eluent was $3.5 \mathrm{mM}$ sodium carbonate, $1.0 \mathrm{mM}$ sodium bicarbonate, flow rate $1.2 \mathrm{ml} / \mathrm{min}$, injection volume $25 \mu \mathrm{l}$.

2.3. Photolysis experiments. Fortified aqueous solutions of lindane, bentazone, and fenitrothion, $3.7 \times$ $10^{-5}, 0.2 \times 10^{-3}$ and $5.4 \times 10^{-5} \mathrm{M}$, respectively, in presence and absence of the photocatalysts $\left(\mathrm{H}_{3} \mathrm{PW}_{12} \mathrm{O}_{40}\right.$ or $\mathrm{K}_{4} \mathrm{SiW}_{12} \mathrm{O}_{40} 7 \times 10^{-4} \mathrm{M}$ ) were made by dissolving certain quantities of substrate in water or in $\mathrm{HClO}_{4} 0.1 \mathrm{M}$ (in the case of $\mathrm{PW}_{12} \mathrm{O}_{40}{ }^{3-}$ ).

Samples of $5 \mathrm{ml}$ of the above fortified solutions were added to a glass cell. After 20 min of deaeration or oxygenation, the cell was covered airtightly with a cap. Photolysis was performed at ambient temperature in the photolysis apparatus. The solution was magnetically stirred throughout the experiment.

\section{RESULTS AND DISCUSSION}

3.1. Photocatalytic degradation of lindane in the presence of $\mathrm{PW}_{12} \mathrm{O}_{40}{ }^{3-}$. Photolysis of aqueous solution of lindane with $\lambda>320 \mathrm{~nm}$, to avoid direct photolysis of the substrate, in the presence of $\mathrm{PW}_{12} \mathrm{O}_{40}{ }^{3-}$, results in its complete photodegradation. Under the reported experimental conditions, decomposition of lindane, in presence of POM, takes place within ca. $60 \mathrm{~min}$. This process takes place in the presence and absence of dioxygen but no photodegradation of lindane takes place in the absence of catalyst under these conditions. The complete photodegradation of lindane leads to its mineralization with $\mathrm{CO}_{2}$ and $\mathrm{Cl}^{-}$as final products (Figure 1). The induction period involved prior to evolution of $\mathrm{CO}_{2}$ indicates the formation of intermediate products. The main reactions occurred is dechlorination of the substrate followed by C-C bond cleavage, as resulted from the kind of the final products.

\subsection{Photocatalytic degradation of bentazone in} the presence of POM $\left(\mathrm{PW}_{12} \mathrm{O}_{40}{ }^{3-}\right.$ and $\left.\mathrm{SiW}_{12} \mathrm{O}_{40}{ }^{4-}\right)$. Effective photodecomposition of bentazone occurs in the presence of POM $\left(\mathrm{PW}_{12} \mathrm{O}_{40}{ }^{3-}\right.$ and $\left.\mathrm{SiW}_{12} \mathrm{O}_{40}{ }^{4-}\right)$. The process takes place in the presence and absence of dioxygen but no photodegradation of bentazone takes place in the absence of catalyst under these conditions. 


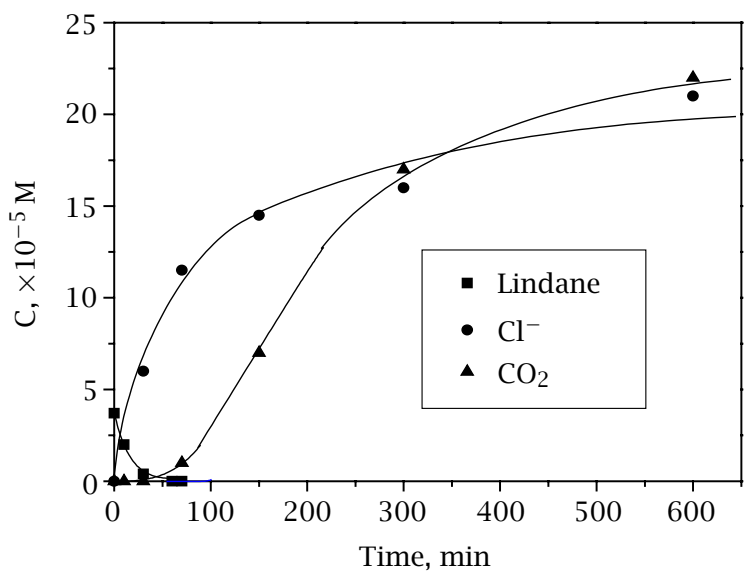

Figure 1. Photodegradation of aqueous solutions of lindane, $\mathrm{C}=3.7 \times 10^{-5} \mathrm{M}(\zeta)$, in presence of $\mathrm{H}_{3} \mathrm{PW}_{12} \mathrm{O}_{40}(7 \times$ $10^{-4} \mathrm{M}$ ) and formation of $\mathrm{CO}_{2}(\mathbf{\Delta})$ and $\mathrm{Cl}^{-}(\bullet)$. (Reprinted from ref. [16]).

In the absence of dioxygen, no regeneration (reoxidation) of the catalyst takes place, at least in the first stages of photolysis. Thus the accumulation of the blue colour of the one-electron reduced POM, with photolysis time, could be followed. Photoreduction of catalyst results in concomitant oxidation of bentazone. Figure 2 shows the formation of the reduced catalyst $\left(\mathrm{PW}_{12} \mathrm{O}_{40}{ }^{4-}\right.$ and $\left.\mathrm{SiW}_{12} \mathrm{O}_{40}{ }^{5-}\right)$ with photolysis time. The initial rates of reduction of $\mathrm{PW}_{12} \mathrm{O}_{40}{ }^{3-}$ and $\mathrm{SiW}_{12} \mathrm{O}_{40}{ }^{4-}$ from the corresponding deoxygenated solutions, calculated from Figure 2 are 9.26 and $1.01 \times 10^{-6} \mathrm{M} \mathrm{min}^{-1}$, respectively. The one order of magnitude lower initial rate of formation for $\mathrm{SiW}_{12} \mathrm{O}_{40}{ }^{4-}$ is in accordance with other results [3] suggesting, generally, the lower photoreactivity of $\mathrm{SiW}_{12} \mathrm{O}_{40}{ }^{4-}$ comparing to $\mathrm{PW}_{12} \mathrm{O}_{40}{ }^{3-}$.

The final products, i.e., $\mathrm{CO}_{2}, \mathrm{SO}_{2}{ }^{2-}$ and $\mathrm{NO}_{3}{ }^{-}$, of the photocatalytic degradation of bentazone in the presence of POM are given in Figure 3. In the presence of $\mathrm{PW}_{12} \mathrm{O}_{40}{ }^{3-}$ a satisfactory mass balance was found between the quantities of bentazone consumed and $\mathrm{CO}_{2}$ evolved. These measurements demonstrate that the substrate is completely mineralized. The formation of $\mathrm{CO}_{2}$ is detected after an induction period, indicating that the process of mineralization goes through several intermediates.

When $\mathrm{SiW}_{12} \mathrm{O}_{40}{ }^{4-}$ was used, $\mathrm{CO}_{2}$ was produced after a longer induction period compared to $\mathrm{PW}_{12} \mathrm{O}_{40}{ }^{3-}$, due to the lower photosensitivity of the $\mathrm{SiW}_{12} \mathrm{O}_{40}{ }^{4-}$. Under these conditions $\mathrm{CO}_{2}$ was monitored only for the first 70 hours, because the illumination time for complete mineralization was too long. The $100 \%$ recovery of sulfate ions in the first stages of the mineralization process indicated the early breaking of the N-S bonds (Figure 3).

Concerning the mineralization of organic nitrogen, complete oxidation to nitrate has not been observed

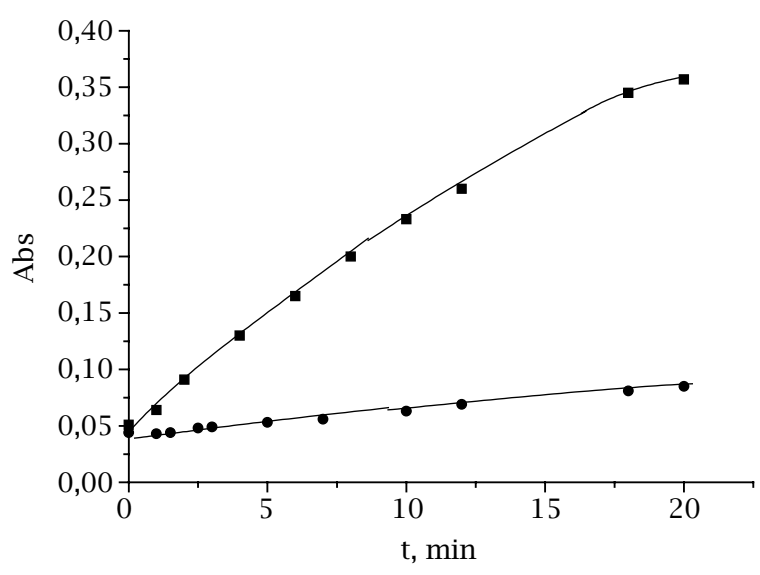

Figure 2. Development of the one-electron reduced POM, with photolysis time of dearated aqueous solutions of bentazone $0.2 \times 10^{-3} \mathrm{M}$, in presence of POM $7 \times 10^{-4} \mathrm{M}$ : (ロ) $\mathrm{PW}_{12} \mathrm{O}_{40}{ }^{4-}, \mathrm{pH}=1, \lambda=752 \mathrm{~nm} ;(\bullet) \mathrm{SiW}_{12} \mathrm{O}_{40}{ }^{5-}, \mathrm{pH}=$ $5.5, \lambda=730 \mathrm{~nm}$.

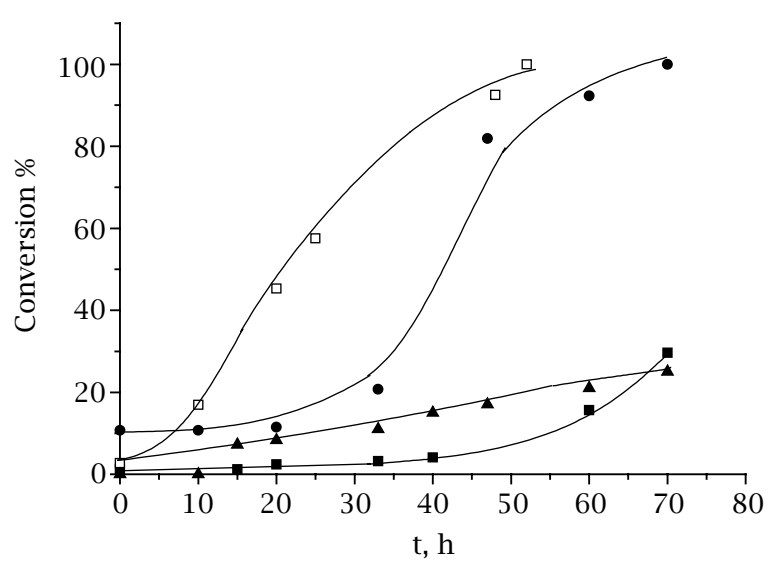

Figure 3. Kinetics of formation of $\mathrm{CO}_{2}$ and inorganic ions during bentazone photocatalytic degradation in the presence of POM; (口) $\mathrm{CO}_{2}$ in the presence of $\mathrm{PW}_{12} \mathrm{O}_{40}{ }^{3-}$;

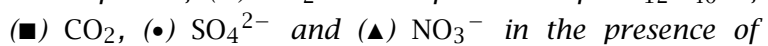
$\mathrm{SiW}_{12} \mathrm{O}_{40}{ }^{4-}$.

(Figure 3). As evidenced by others for $\mathrm{TiO}_{2}$ photocatalysis [19] this is due to ammonium ions also present in variable amounts in most cases or to the existence of other nitrogen-containing species, such as hydroxylamine. Nitrite ions could not detected in our system.

3.3. Photocatalytic degradation of fenitrothion in the presence of $\mathrm{PW}_{12} \mathrm{O}_{40}{ }^{3-}$. The photocatalytic treatment of fenitrothion in aqueous solutions in the presence of POM leads to the decompostition of the pesticide within ca. 60 min (Figure 4). The decomposition of fenitrothion during the same photolysis time, in the absence of POM is less than $6 \%$. 


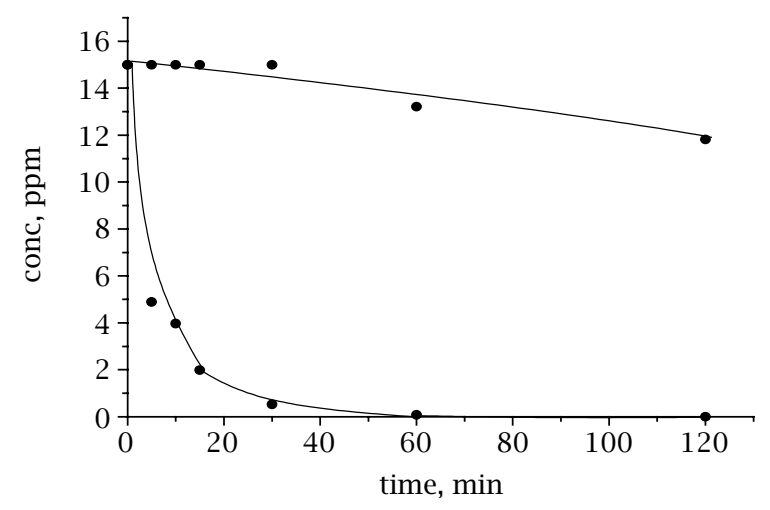

Figure 4. Photodegradation of aqueous solutions of fenitrothion, $\mathrm{C}=5.45 \times 10^{-5} \mathrm{M}$ : (...) no catalyst; (-) in presence of $\mathrm{H}_{3} \mathrm{PW}_{12} \mathrm{O}_{40}\left(7 \times 10^{-4} \mathrm{M}\right)$.

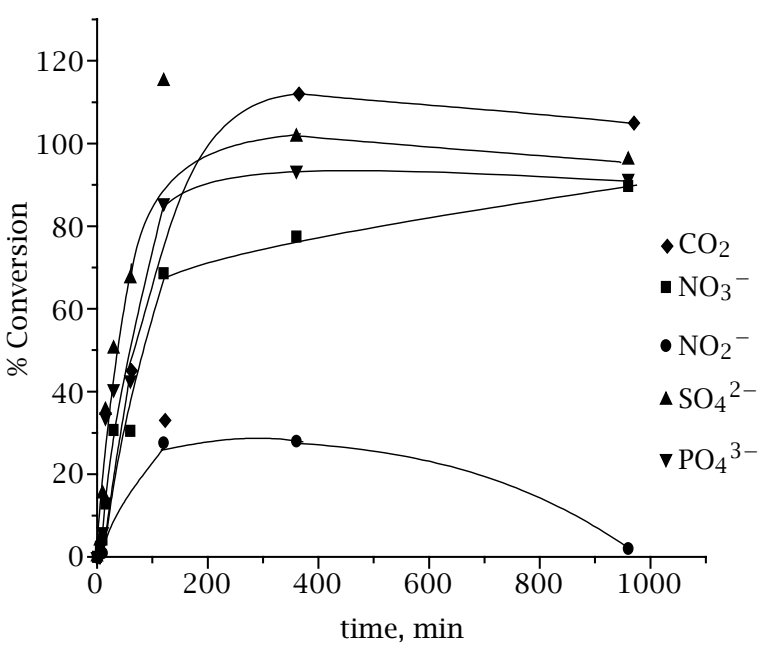

Figure 5. Formation of $\mathrm{CO}_{2}$ and inorganic ions upon photocatalytic degradation of fenitrothion in the presence of POM.<smiles>COP(=S)(OC)Oc1ccc([N+](=O)[O-])c(C)c1</smiles>

Fenitrothion<smiles>COP(=O)(OC)Oc1ccc([N+](=O)[O-])c(C)c1</smiles>

Fenitrooxon HPLC GC-MS<smiles>Cc1cc(O)ccc1[N+](=O)[O-]</smiles>

3-methyl-4-nitrophenol HPLC GC-MS<smiles>Cc1cc(O)ccc1O</smiles>

VI

2-methyl-hydroquinone HPLC<smiles></smiles>

2-methyl-1,4-benzoquinone HPLC GC-MS<smiles>COP(=S)(OC)Oc1ccc([N+](=O)[O-])c(C=O)c1</smiles>

Formylfenitrothion GC-MS<smiles>COc1ccc([N+](=O)[O-])c(C)c1</smiles>

$\mathrm{V}$

3-methyl-4-nitroanisole HPLC GC-MS

Scheme 2. Intermediates formed during the photocatalytic degradation of fenitrothion by $\mathrm{H}_{3} \mathrm{PW}_{12} \mathrm{O}_{40}$. (Reprinted from ref. $[17])$. 
The total mineralization of fenitrothion, i.e., formation of $\mathrm{CO}_{2}$ and inorganic ions $\left(\mathrm{PO}_{4}{ }^{3-}, \mathrm{SO}^{2-}, \mathrm{NO}_{3}{ }^{-}\right)$ occurred within a few hours (Figure 5). A satisfactory mass balance was found among the quantities of fenitrothion consumed and $\mathrm{CO}_{2}, \mathrm{PO}_{4}{ }^{3-}, \mathrm{SO}_{4}{ }^{2-}$, and $\mathrm{NO}_{3}{ }^{-}$ evolved. The final, almost total, recovery of nitrate anions took place through the formation of nitrites that afterwards were oxidized to nitrates.

The main reactions were denitration and desulfurization followed by C-C bond cleavage, in accordance with the photocatalytic degradation of the other target pesticides.

\subsection{Intermediates in the photodecomposition of} fenitrothion. A detail study of the photodegradation of fenitrothion (I) reveals the formation and decay of several intermediates, prior to the final decomposition to $\mathrm{CO}_{2}$ and inorganic ions (Scheme 2). Five of these photodegradation intermediates, i.e., fenitrooxon (II), 3-methyl-4-nitrophenol (IV), 3-methyl-4nitroanisole (V), 2-methyl-hydroquinone (VI), and 2methyl-1,4-benzoquinone (VII), were identified with HPLC-DAD by comparing their retention times and spectral data (obtained by DAD) with those of commercially available standards. The presence of II, IV, V, and VII was confirmed with GC-MS/EI by comparing their mass spectra with those of commercially available standards. Two others intermediates, formylfenitrothion (III), and O,O,S-trimethyl phosphorothioate (VIII) were identified with GC-MS/EI by comparing their mass spectra with those reported in the literature.

The formation of several intermediates prior to mineralization suggests a rather complicated mechanism of decomposition, where $\mathrm{OH}^{*}$ radicals seem to play an important role. This conclusion comes from the verification of $\mathrm{OH}$ addition (intermediates IV and VI) and $\mathrm{H}$ abstraction (intermediate III) which are typical processes for $\mathrm{OH}^{\prime}$ radicals.

\section{CONCLUSIONS}

The photocatalytic degradation of diversified pesticides can been achieved in the presence of polyoxometallates, as photocatalysts, upon illumination in the UV/Vis light. The decomposition process is not selective driving to mineralization all target substrates, i.e., production of $\mathrm{CO}_{2}, \mathrm{H}_{2} \mathrm{O}$ and the corresponding inorganic anions. The induction period prior to $\mathrm{CO}_{2}$ evolution, indicates the formation of intermediates, through a rather complicated mechanism. Many of these intermediates were identified in details in the case of fenitrothion. The characteristic reactions that take place in all studied cases consist of hydroxylation, $\mathrm{H}-$ abstraction, dehalogenetion, denitration, desulfurization, and breaking of the $\mathrm{C}-\mathrm{C}$ bond, as resulted from the intermediates and final products.

\section{REFERENCES}

[1] E. Androulaki, A. Hiskia, D. Dimoticali, C. Minero, P. Calza, E. Pelizzetti, and E. Papaconstantinou, Environ. Sci. Technol. 34 (2000), 2024.

[2] A. Mylonas, A. Hiskia, and E. Papaconstantinou, J. Mol. Catal. A: Chem. 114 (1996), 191.

[3] A. Mylonas and E. Papaconstantinou, J. Photochem. Photobiol. A: Chem. 94 (1996), 77.

[4] M. T. Pope, in Heteropoly and Isopoly Oxometallates in Inorganic Chemistry Concepts 8, (C. K. Jorgensen et al., Eds.), Springer Verlag, West Berlin, 1983.

[5] M. T. Pope and A. Muller, Angew. Chem. Int. Ed., Engl. 30 (1991), 34.

[6] V. W. Day and W. G. Klemperer, Science 228 (1985), 533.

[7] A. Hiskia, A. Mylonas, and E. Papaconstantinou, Chemical Society Reviews 30 (2001), 62.

[8] A. Hiskia and E. Papaconstantinou, Inorg. Chem. 31 (1992), 163.

[9] Lindane, EHC 124, IPCS, 1991, WHO, Geneva and references therein.

[10] S. Chiron, E. Martinez, D. Barceló, J. Chromatogr. A 665 (1994), 283.

[11] J. R. Chambers and H. W. Chambers, in Pesticide Transformation Products, (L. Somasundaram and J. R. Coats, Eds.), A.C.S Symp. Ser., 459, 1991, p. 32.

[12] Ch. Guillard, P. Pichat, G. Huber, and C. Hoang-Van, J. Adv. Oxid. Technol. 1 (1996), 53.

[13] E. Pelizzetti, V. Maurino, C. Minero, O. Zerbinati, and E. Borgarello, Chemosphere 18 (1989), 1437.

[14] M. Kerzhentsev, C. Guillard, J. M. Herrmann, P. Pichat, Catalysis Today 27 (1996), 215.

[15] A. Hiskia, A. Mylonas, D. Tsipi, and E. Papaconstantinou, Pestic. Sci. 50 (1997), 171.

[16] A. Hiskia, E. Androulaki, A. Mylonas, S. Boyatzis, D. Dimotikali, C. Minero, E. Pelizzetti, and E. Papaconstantinou, Research Chem. Intermediates 26 (2000), 235.

[17] P. Kormali, D. Dimoticali, D. Tsipi, A. Hiskia, and E. Papaconstantinou, Appl. Catal.: B: Environmental, in press.

[18] M. T. Pope and G. M. Varga, Inorg. Chem. 5 (1966), 1249.

[19] E. Pramauro, A. B. Prevot, M. Vincenti, and G. Brizzolesi, Environ. Sci. Technol. 31 (1997), 3126. 


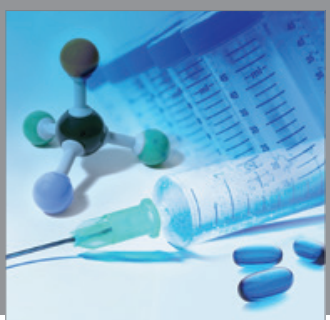

International Journal of

Medicinal Chemistry

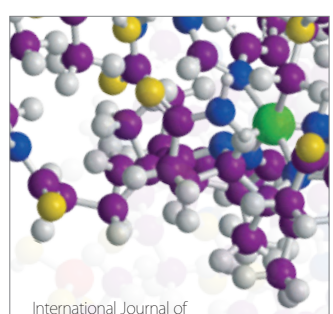

Carbohydrate Chemistry

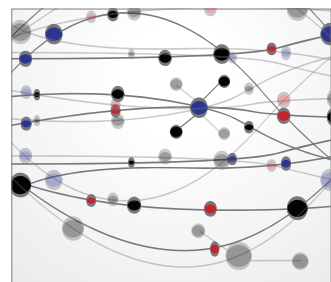

The Scientific World Journal
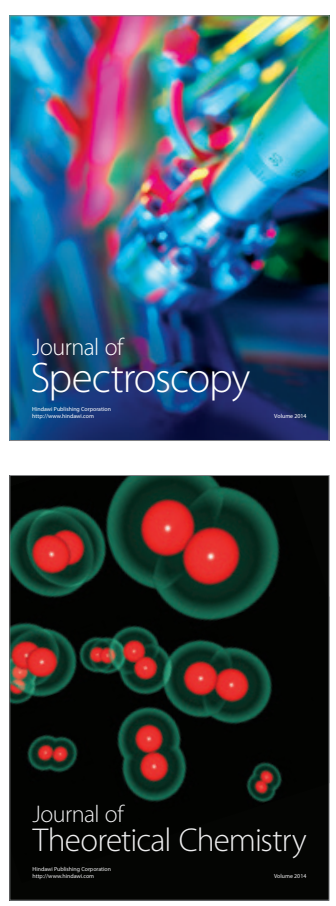
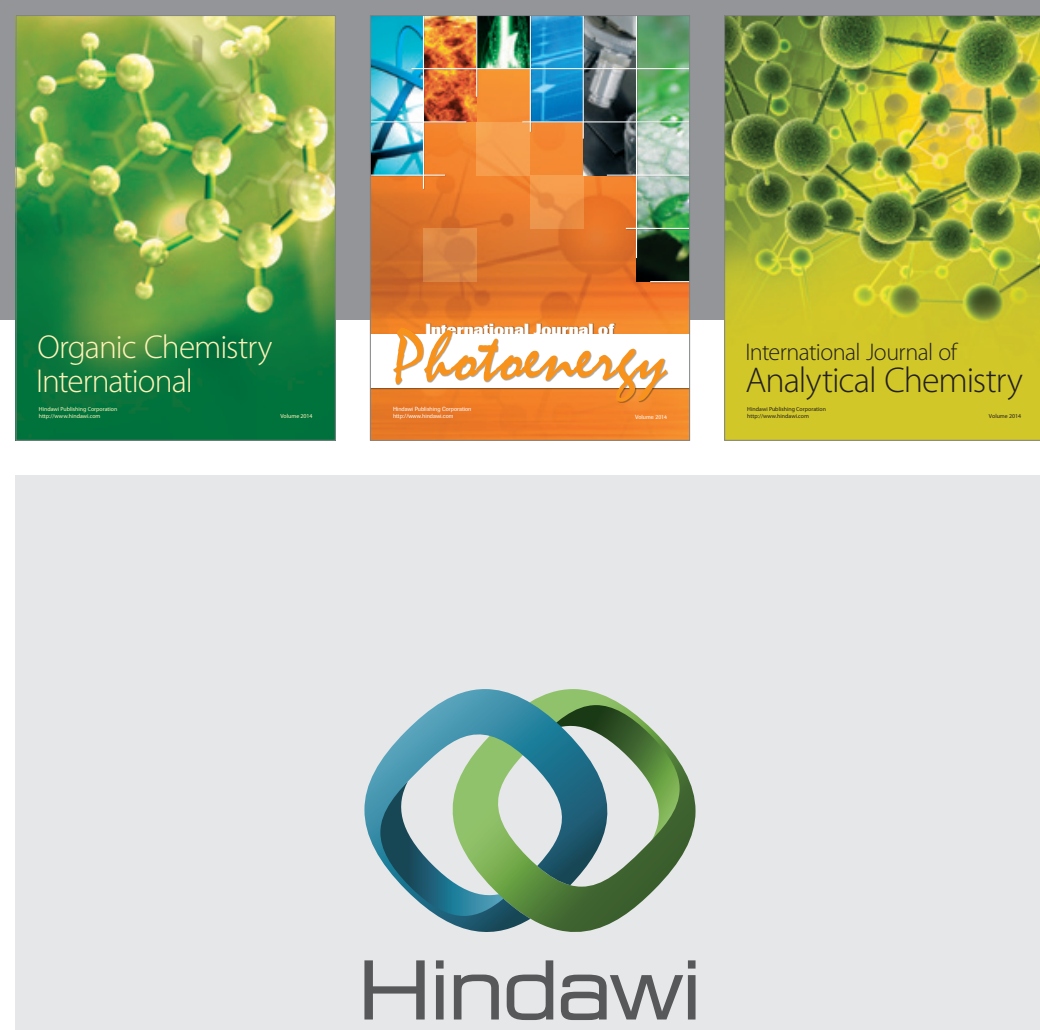

Submit your manuscripts at

http://www.hindawi.com
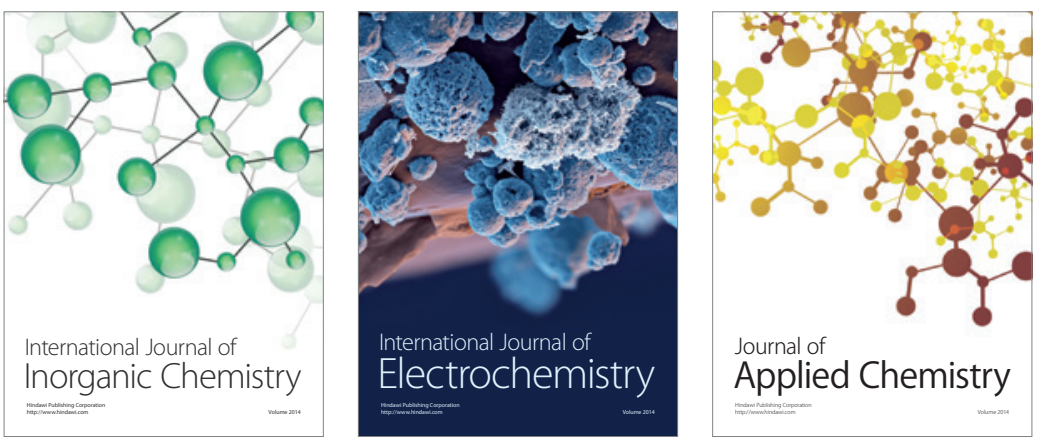

Journal of

Applied Chemistry
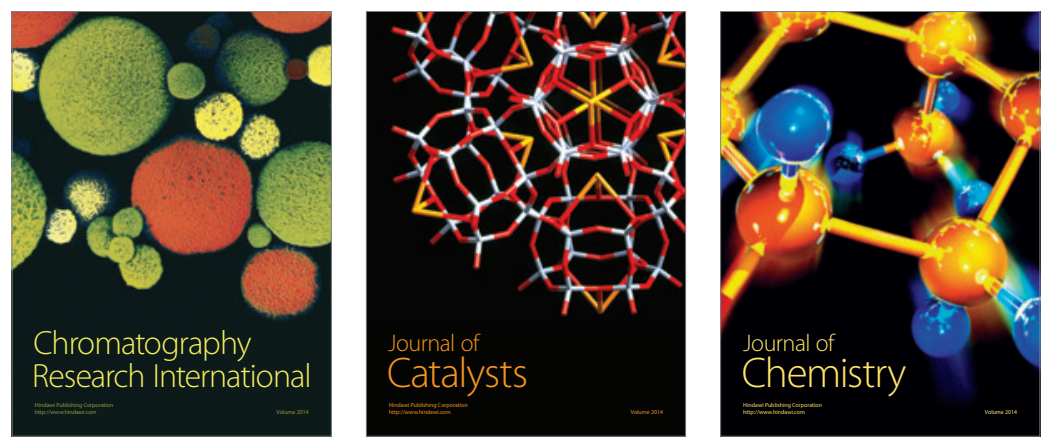
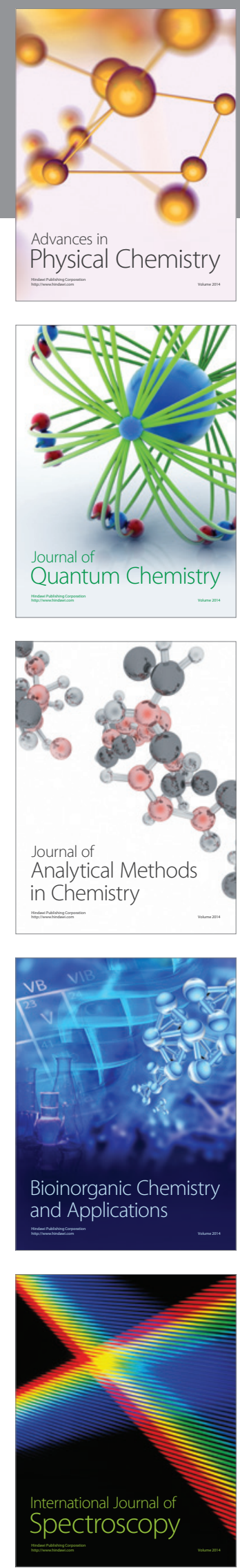